\title{
LESSON STUDY SEBAGAI SARANA MENINGKATKAN KUALITAS DAN PROFESIONALITAS PEMBELAJARAN
}

\author{
Nanang Nuryanta \\ Dosen Prodi Pendidikan Agama Islam FIAI-UII \\ email: nanangnury@gmail.com
}

\section{Abstract}

Several factors can affect the learning process, that are teachers, learners, means, tools and media available and environment. Although that influence the success of learning a lot but can not be denied that teacher is the main factor and decisive for the success of the learning process. Teacher or educator professional will be able ensure learning process to be good. However, some facts indicate that many teachers teach and make the learning process as simply "just obligations", they do not realize that the teacher is a profession who demands professionalism in practice. Therefore the need to model a new approach in coaching teachers, one of them with Lesson Study, namely learning model teachers will be able to be effectively implemented in educational institutions on the condition that there is a shared commitment to strong from the teachers themselves, school principals and the Education Department is supported by involvement of education experts. Lesson Study is not one learning model teaching profession only, therefore, needs to be combined with other models.

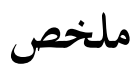

من العوامل التي تؤثر على عملية التعلم هي من قبل المعلم والمتعلمين والأدوات وسائل الإعلام المتاحة وكذلك من ناحية البيئة. ولكن من هذه العوامل كلها أهمها المعلم. يكون المعلمون أو المدربون ذووا القدرة المهنية قادرين على التأكد من عملية التعلم أن تكون جيدة. ووع ذلك، بعض الحقائق تشير إلى أن العديد من المعلمين جعلوا عملية التعلم بأهما "بحرد التزامات"، أهم لا يدركون أن المعلم هو المهنة التي تتطلب الاحتراف في الممارسة العملية. وبالتالي فإن الحاجة إلى نموذج لنهج جديد في تدريب 


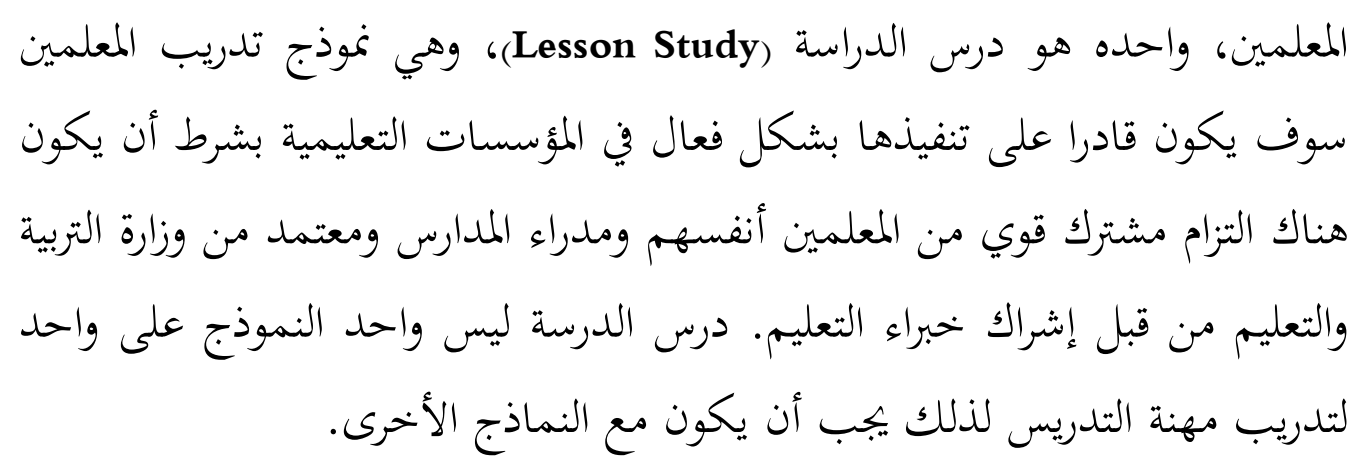

Keywords: Lesson Studi, Pembelajaran, Guru, dan Pembinaan

\section{A. Pendahuluan}

Profesi guru harus dihargai dan dikembangkan sebagai profesi yang bermartabat sebagaimana diamanatkan dalam Undang-Undang Nomor 14 Tahun 2005 tentang Guru dan Dosen. Hal ini dikarenakan guru merupakan tenaga profesional yang mempunyai fungsi, peran, dan kedudukan yang sangat penting dalam mencapai visi pendidikan 2025 yaitu menciptakan insan Indonesia cerdas dan kompetitif. Guru adalah bagian integral dari organisasi pendidikan di sekolah. Sebuah organisasi, termasuk organisasi pendidikan di sekolah, perlu dikembangkan sebagai organisasi pembelajar, agar mampu menghadapi perubahan dan ketidakpastian yang merupakan ciri kehidupan modern. Salah satu karakter utama organisasi pembelajar adalah senantiasa mencermati perubahan internal dan eksternal yang diikuti dengan upaya penyesuaian diri dalam rangka mempertahankan eksistensinya. Syarat mutlak terciptanya organisasi pembelajar adalah terwujudnya masyarakat pembelajar di tubuh organisasi tersebut. Hal ini mudah dipahami, mengingat kinerja suatu organisasi adalah merupakan produk kinerja kolektif semua unsur di dalamnya, termasuk sumber daya manusia.

Guru memiliki posisi sentral dan strategis dalam konteks pengembangan pengajaran dan pembelajaran pada suatu institusi atau organisasi pendidikan, khususnya sekolah. Dalam konteks sekolah, guru secara individu maupun secara bersama-sama dengan masyarakat seprofesinya, harus menjadi bagian dari organisasi pembelajar melalui keterlibatannya secara sadar dan sukarela 
serta terus menerus dalam berbagai kegiatan belajar guna mengembangkan profesionalismenya. Salah satu bentuk aktualisasi tugas guru sebagai tenaga profesional adalah diterbitkannya Undang-Undang Nomor 20 Tahun 2003 tentang Sistem Pendidikan Nasional, Undang Undang No 14 Tahun 2005 tentang Guru dan Dosen dan Peraturan Pemerintah Nomor 19 Tahun 2005 tentang Standar Nasional Pendidikan. Terbitnya undang-undang maupun peraturan pemerintah tersebut menjadi acuan, pedoman dan pendorong yang sangat kuat akan pentingnya profesionalitas guru dalam melaksanakan fungsi, tugas, peran dan kedudukannya dalam proses pendidikan.

Proses pendidikan yang baik pasti berawal dari proses pembelajaran yang berkualitas dan efektif. Proses pembelajaran yang efektif dapat terjadi kalau "learning actor", yaitu guru, optimal dan professional dalam menjalankannya sehingga mencapai hasil yang diharapkan. James L. Mursell (1954) dalam Santosa menyatakan bahwa:

"Successful teaching is teaching that brings about effective learning. The decisive question is not what methods or procedures are employed, or whether they are old-fashioned or modern, time tasted or experimental, conventional or progressive. All such considerations may be important but none of them is ultimate, for they have to do with means, not ends. The ultimate criterion for success in teaching is result." 1

Beberapa factor yang dapat mempengaruhi proses pembelajaran, di antaranya adalah factor guru, factor peserta didik, sarana, alat dan media yang tersedia serta factor lingkungan (Sanjaya, 2008:52). Meskipun yang mempengaruhi kesuksesan pembelajaran banyak namun tidak dapat dipungkiri bahwa factor pendidik merupakan factor yang sentral dan menentukan bagi keberhasilan suatu proses pembelajaran. Guru atau pendidik yang professional akan mampu ensure proses pembelajaran menjadi baik. Namun beberapa fakta menunjukkan bahwabanyakguru mengajardanmelakukan proses pembelajaran hanya sebagai "penggugur kewajiban", mereka tidak menyadari bahwa guru adalah sebuah profesi yang menuntut profesionalisme dalam praktiknya. Banyak guru yang hanya memberikan tugas kepada peserta didik sementara

1 Adam Santosa. Pengaruh Pembelajaran Dengan Lesson Study Terhadap Hasil Belajar Pendidikan Agama Islam (PAI) Di SMP Negeri 1 Srandakan Bantul Yogyakarta Tahun Pelajaran 2013/2014. Proposal Tesis. Yogyakarta: PPS MSI UII tahun 2014, hal. 3. 
yang bersangkutan tidak ada di kelas dengan berbagai alasan karena tugas administrative, rapat, seminar di luar sekolah dan lain-lain. Bahkan sertifikasi guru sekarang ini belum cukup signifikan meningkatkan profesionalitas guru. Menurut data Kementerian PPN/Bappenas (2014:18) dalam Nuryanta ${ }^{2}$ menyebutkan bahwa "sementara program sertifikasi memang sudah berhasil meningkatkan kesejahteraan guru tetapi belum mampu meningkatkan kualitas mutu dan hasil pembelajaran peserta didik".

Proses dari implementasi undang-undang tersebut terutama yang berkaitan dengan sertifikasi guru sudah mulai dilakukan pemerintah sejak tahun 2006. Andaikan proses sertifikasi sudah berjalan dan sebagian besar atau seluruh guru sudah bersertifikat profesi, apakah peningkatan mutu pendidikan sudah tuntas? Akan tetapi, inovasi dan peningkatan mutu pendidikan merupakan proses yang bekesinambungan yang melibatkan seluruh komponen dalam pendidikan.

Fakta di atas, menunjukkan keadaan "ironis" dari yang seharusnya. Kondisi tersebut tidak boleh dibiarkan terjadi secara terus menerus namun harus dihentikan dan perlu ada solusi untuk mengembalikan posisi, fungsi, peran guru pada kepatuhan pofesinya. Banyak cara yang ditempuh oleh pemerintah dengan membuat program dalam rangka mengembalikan profesionalitas guru, antara lain: pengembangan keprofesian berkelanjutan (PKB), kerja kelompok guru (KKG), musyawarah guru mata pelajaran (MGMP), penataran guru, inhouse training, Lesson Study, penilaian kinerja guru dan penelitian tindakan kelas. Peningkatan mutu pendidikan dapat dimulai dengan meningkatkan mutu guru dalam mengajar dan berperilaku profesional. Berbagai penataran dan pelatihan guru menjadi salah satu bentuk dari upaya tersebut. Akan tetapi, seringkali hal itu tidak membekas dalam keseharian aktivitas guru. Hal inilah yang mendasari perlunya perbaikan yang menitikberatkan kepada kondisi riil di lapangan, mulai dari kondisi di kelas, sekolah, dan guru. Upaya perbaikan terus menerus harus dimulai dari bawah dan tidak hanya tuntutan dari atas.

Berangkat dari berbagai program yang ditawarkan untuk memperbaiki kinerjaguruagarmencapai profesionalisme, padamakalahinipenulishanyaakan mengambil satu topic yang terkait dengan Lesson Study. Beberapa pertanyaan

2 Nanang Nuryanta, Reorientasi Pendidikan Nasional Dalam Menyiapkan Daya Saing Bangsa. Makalah. Bandung: SPS UPI tahun 2014, hal. 11. 
untuk menghantarkan pembahasan dalam makalah ini adalah: Apakah Lesson Study? Apa saja langkah-langkah Lesson Study? Bagaimanakah caranya agar Lesson Study tetap konsisten digunakan sebagai sarana meningkatkan kualitas dan profesionalitas dalam pembelajaran? Pertanyaan-pertanyaan tersebut akan dibahas melalui uraian berikut.

\section{B. Landasan Pemikiran Lesson Study}

Ada beberapa landasan pemikiran yang mendasari pembahasan Lesson Study, baik dari sisi yuridis, filosofis maupun historis.

\section{Landasan Yuridis}

Secara yuridis, Lesson Study memiliki acuan yang sangat kuat, yaitu:

a. Pancasila dan Undang-Undang Dasar 1945.

b. Undang-Undang Nomor 20 Tahun 2003 Tentang Sistem Pendidikan Nasional.

c. Undang-Undang Nomor 14 Tahun 2005 Tentang Guru dan Dosen.

d. Peraturan Pemerintah Nomor 19 Tahun 2005 Tentang Standar Nasional Pendidikan.

Dalam UU Nomor 20 Tahun 2003 Tentang Sistem Pendidikan Nasional telah disebukan bahwa:

Bab I pasal 1 butir 6 disebutkan bahwa: "pendidik adalah tenaga kependidikan yang berkualifikasi sebagai guru, dosen, konselor, pamong belajar, widyaiswara, tutor, instruktur, fasilitator dan sebutan lain yang sesuai dengan kekhususannya, serta berpartisipasi dalam menyelenggarakan pendidikan".

Sedangkan pada Bab XI pasal 39 menjelaskan bahwa: "pendidik merupakan tenaga profesional yang bertugas merencanakan dan melaksanakan proses pembelajaran, menilai hasil pembelajaran, melakukan pembimbingan dan pelatihan, serta melakukan penelitian dan pengabdian kepada masyarakat, terutama bagi pendidik pada perguruan tinggi".

Pada Bab XI pasal 40 ayat (1) bahwa: "Pendidik dan tenaga kependidikan berhak memperoleh: (a) penghasilan dan jaminan kesejahteraan sosial yang pantas dan memadai; (b) penghargaan sesuai dengan tugas dan prestasi kerja; (c) pembinaan karier sesuai dengan tuntutan pengembangan kualitas; (d) 
perlindungan hukum dalam melaksanakan tugas dan hak atas hasil kekayaan intelektual; dan (e) kesempatan untuk menggunakan sarana, prasarana, dan fasilitas pendidikan untuk menunjang kelancaran pelaksanaan tugas".

Sementara Bab XI pasal 40 ayat (2), yaitu: "Pendidik dan tenaga kependidikan berkewajiban: (a) menciptakan suasana pendidikan yang bermakna, menyenangkan, kreatif, dinamis, dan dialogis; (b) mempunyai komitmen secara profesional untuk meningkatkan mutu pendidikan; dan (c). memberi teladan dan menjaga nama baik lembaga, profesi, dan kedudukan sesuai dengan kepercayaan yang diberikan kepadanya".

Adapun Undang-Undang Nomor 14 Tahun 2005 Tentang Guru dan Dosen menegaskan bahwa menurut:

Bab IV pasal 8: "Guru wajib memiliki kualifikasi akademik, kompetensi, sertifikat pendidik, sehat jasmani dan rohani, serta memiliki kemampuan untuk mewujudkan tujuan pendidikan nasional".

Bab IV pasal 10 (1) “Kompetensi guru sebagaimana dimaksud dalam Pasal 8 meliputi kompetensi pedagogik, kompetensi kepribadian, kompetensi sosial, dan kompetensi profesional yang diperoleh melalui pendidikan profesi".

Pada pasal20dijelaskanbahwa:"Dalammelaksanakantugaskeprofesionalan, guru berkewajiban : (a) merencanakan pembelajaran, melaksanakan proses pembelajaran yang bermutu, serta menilai dan mengevaluasi hasil pembelajaran; (b) meningkatkan dan mengembangkan kualifikasi akademik dan kompetensi secara berkelanjutan sejalan dengan perkembangan ilmu pengetahuan, teknologi dan seni".

Pasal 32, menjelaskan bahwa guru berhak memperoleh: (a) Pembinaan dan pengembangan guru meliputi pembinaan dan pengembangan profesi dan karier. (b) Pembinaan dan pengembangan profesi guru meliputi kompetensi pedagogik, kompetensi kepribadian, kompetensi sosial dan kompetensi profesional.

Selanjutnya pada pasal 34: "Pemerintah dan pemerintah derah wajib membina dan mengembangkan kualifikasi akademik dan kompetensi guru pada satuan pendidikan yang diselenggarakan oleh pemerintah, pemerintah daerah dan/atau masyarakat".

Adapun Peraturan Pemerintah Nomor 19 Tahun 2005 Tentang Standar Nasional Pendidikan, Bab IV pasal 19 (1) menyebutkan bahwa: "Proses 
pembelajaran pada satuan pendidikan diselenggarakan secara interaktif, inspiratif, menyenangkan, menantang, memotivasi peserta didik untuk berpartisipasi aktif, serta memberi ruang yang cukup bagi prakarsa, kreativitas dan kemandirian sesuai bakat, minat dan perkembangan fisik serta psikologis peserta didik".

Sedangkan pasal19(3)menyebutkan: "Setiap satuan pendidikan melakukan perencanaan proses pembelajaran, pelaksanaan proses pembelajaran, penilaian hasil pembelajaran dan pengawasan proses pembelajaran untuk terlaksananya proses pembelajaran yang efektif dan efisien".

Selain legalitas di atas, Lesson Study juga mengacu pada konsep PAIKEM GEMBROT (Pembelajaran Aktif, Inovatif, Efektif dan Menyenangkan dikombinasikan dengan Gembira, Efisien, Mengarah, Berbobot, Reaktif, Orientasi pada Tujuan) yang berlandaskan pada: (a) Undang-Undang Dasar Republik Indonesia tahun 1945, pasal 31 menyatakan bahwa "Setiap warga Negara berhak mendapatkan pendidikan yang layak". (b) UU No. 23 Tahun 2002 tentang Perlindungan Anak pasal 9, menyatakan bahwa "Setiap anak berhak memperoleh pendidikan dan pembelajaran dalam rangka pengembangan pribadinya dan tingkat kecerdasannya sesuai dengan minat dan bakatnya". (c) UU No. 20 Tahun 2003 Sistem Pendidikan Nasional pada Bab I Ketentuan umum pasal 1 tentang definisi pendidikan menekankan kepada mewujudkan suasana belajar dan proses pembelajaran dan keterlibatan peserta didik secara aktif mengembangkan potensi dirinya". Sedangkan pada Bab V pasal 1-b menyatakan bahwa "Setiap peserta didik pada setiap satuan pendidikan berhak mendapatkan pelayanan pendidikan sesuai bakat, minat dan kemampuannya"

Dengan demikian jelas sekali bahwa guru secara legalitas memiliki acuan yang kuat untuk dapat menjadi professional dan berkualitas.

\section{Landasan Filosofis}

Lesson Study merupakan salah satu bentuk konstruktivisme pembinaan guru (in-service) yang dilakukan untuk meningkatkan profesionalisme guru. Lesson Study dilakukan di wilayah guru mengajar dengan menggunakan 
kelas dalam lingkungan nyata, sehingga akan membiasakan guru bekerja secara kolaboratif baik dengan guru bidang studi dan dengan guru diluar bidang studi, bahkan dengan masyarakat. Lesson Study merupakan kolaboratif antara guru dalam menyusun rencana pembelajaran beserta research lesson-nya, pelaksanaan KBM di kelas yang disertai observasi dan refleksi. Dengan Lesson Study para guru dapat leluasa meningkatkan kinerja dan keprofesionalannya yang akhirnya dapat meningkatkan mutu pembelajaran dan menghasilkan peserta didik yang berkualitas tinggi.

Karena Lesson Study adalah penguatan pada profesi, maka secara filosofis, aktifitas Lesson Study harus mengikuti persyaratan suatu profesi sebagaimana dikemukan oleh Corwin (1965) dalam Ornstein, dkk (2011:29) harus memiliki:

A sense of public service; a lifetime commitment to carrier; $b$. A defined body of knowledge and skills beyond that grasped by laypeople; c. A lengthy period of specialized training; $d$. Control over licensing standards and/or entry requirements; e. Autonomy in making decisions about selected spheres of work; $f$. An acceptance of responsibility for judgments made and acts performed related to services rendered; a sets of performance standards; $g$. A self-governing organization composed of members of the profession; $h$. professional association and/or elite groups to provide recognition for individuals achievements; i. A code of ethics to help to clarify ambiguous matters or doubtful points related to services rendered; and $j$. High prestige and economic standing.

Selain itu, sebagai sebuah profesi, guru harus dikerjakan dengan profesionalisme terdapat dalam Al-Qur'an Surat Al Isra' (17) ayat 84:

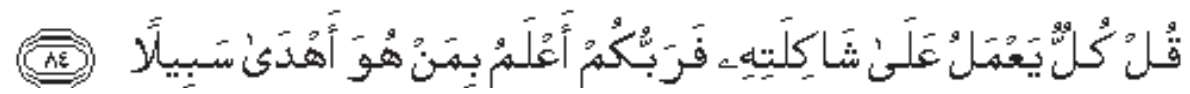

Artinya: "Katakanlah: “Tiap-tiap orang berbuat menurut keadaannya masing-masing". Maka Tuhanmu lebih mengetahui siapa yang lebih benar jalannya".

Demikian pula dalam QS. At-Taubah (9) ayat 105, yaitu:

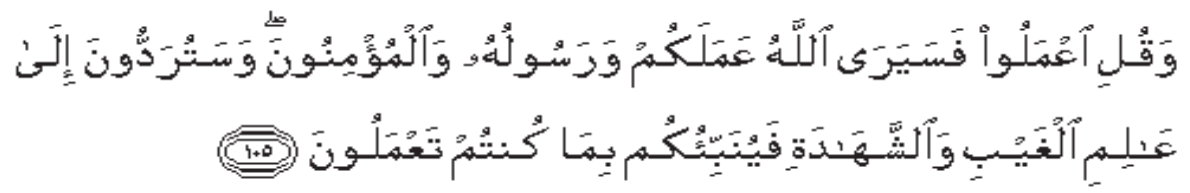


Artinya: "Dan katakanlah: "Bekerjalah kamu, maka Allah dan RasulNya serta orang-orang mukmin akan melihat pekerjaanmu itu, dan kamu akan dikembalikan kepada (Allah) Yang Mengetahui akan yang gaib dan yang nyata, lalu diberitakanNya kepada kamu apa yang telah kamu kerjakan".

\section{Landasan Historis-Empiris}

Lesson Study pertama kali dikembangkan di Jepang dan menjadi model yang terkenal dalam upaya meningkatkan mutu pendidikan melalui peningkatan kualitas pembelajaran. Tahun 1900 di Jepang berkomitmen meningkatkan kualitas pendidikan melalui pembelajaran. Lesson Study adalah suatu sekolah dan dikenal sebagai Konaikenshu, dikembangkan awal tahun 1960 dan merupakan sekolah training (school training). Atau ada yang berpendapat bahwa istilah Lesson Study muncul di Jepang sebagai kenkyuu jugyou, apabila diterjemahkan secara bebas dari kenkyuu berarti riset dan jogyu berarti pelajaran atau lesson. Lesson Study melepaskan ketergantungan guru dari kurikulum yang rigid, membawa guru dan siswa menjadi lebih aktif dan memiliki visi lebih luas serta memberikan ruang bagi munculnya sebuah solusi pembelajaran yang bersifat aplikatif.

Salah satu tokoh reformasi pendidikan Jepang yang dikenal sebagai suhu reformasi, Manabu Sato, yang merupakan seorang dosen di Universitas Tokyo mengemukakan perlunya perubahan dalam pola pembelajaran yang tertutup. Perubahan itu berupa penciptaan masyarakat belajar di sekolah dan membuka seluas-luasnya proses pembelajaran di kelas untuk diamati oleh siapa saja. Teknik pembelajaran yang terbuka dan menerima masukan dari siapa saja yang melihatnya, sehingga proses pembelajaran dapat dikembangkan. Teknik yang demikian ini ia namakan sebagai Lesson Study (studi pembelajaran).

Selanjutnya, yang juga dijadikan alasan lahirnya Lesson Study adalah hasil study/penelitian matematika dan ilmu pengetahuan internasional ketiga, menunjukkan bahwa 20 dari 41 negara memperoleh sekor rerata lebih tinggi dari AS. Hal inilah yang mendorong AS study banding pembelajaran matematika ke Jepang. Pemerintah Amerika merasa penasaran apa yang menyebabkan Jepang memiliki prestasi lebih dibanding negaranya. Oleh karenanya, Amerika melakukan studi komparatif ke Jepang untuk melihat 
model pembelajaran yang dikembangkan di Jepang yang selanjutnya diterapkan di negaranya.

Sebagai perbandingan dapat dilihat paparan pola pembelajaran antara Jepang dengan Amerika selengkapnya dapat dilihat pada gambar 1.1 di bawah ini:

\section{Gambar 1}

Perbandingan Aktifitas Guru dalam Pengembangan Pembelajaran

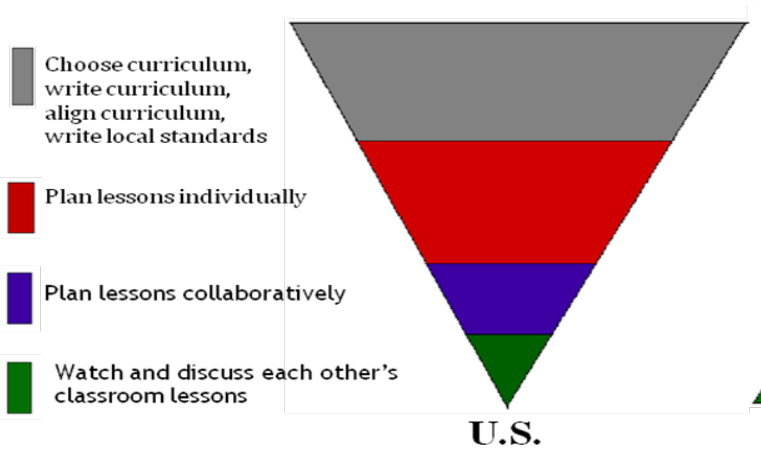

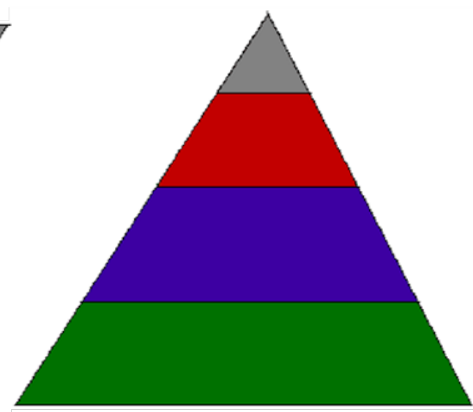

JAPAN

Sumber: Diadaptasi dari Lesson Study Tuwuh, ppt, 2014

Berdasarkan paparan Lidinillah (2014) Mulai tahun 1995, Lesson Study menyebar ke berbagai negara tidak terkecuali Amerika Serikat melalui kegiatan The Third International Mathematics and Science Study (TIMSS). Di Indonesia sendiri, Lesson Study berkembang melalui Indonesian Mathematics and Science Teacher Education Project (IMSTEP). Pelaksanaannya dimulai tahun 1998 melalui tiga IKIP yaitu IKIP Bandung (Universitas Pendidikan Indonesia), IKIP Yogyakarta (Universitas Negeri Yogyakarta), dan IKIP Malang (Universitas Negeri Malang). Kegiatan ini juga berkerjasama dengan Japan International Cooperation Agency (JICA). Bahkan menurut Santosa (2014:2) pada bulan Desember 2007 SMP Negeri 1 Srandakan ditetapkan sebagai salah satu sekolah pilot Lesson Study Berbasis Sekolah (LSBS) oleh Tim Japan International Cooperation Agency (JICA). JICA memilih enam sekolah dari tiga kabupaten yaitu kabupaten Sumedang, kabupaten Bantul dan kabupaten Pasuruan, masing-masing kabupaten dipilih dua sekolah sebagai pilot LSBS.

Jika dilihat dari mapping lokasi sesungguhnya beberapa sekolah yang dijadikan piloting tidak termasuk dalam wilayah pusat kota akan 
tetapi cenderung di wilayah pinggir. Namun jika diamati dari sisi kualitas sekolahnya, sekolah yang dipilih masuk kategori menengah ke atas. Mungkin ini didasarkan atas pertimbangan khusus untuk melihat signifikansi perubahannya, karena sekolah "level tengah" cenderung lebih mudah untuk menerima perubahan dan memiliki "kepatuhan" yang tinggi dibanding sekolah yang dikategorikan "maju" yang sudah terbiasa dengan inovasi dan perubahan. Demikian halnya dengan sekolah pinggiran atau "marginal school", tidak dipilih karena cenderung lebih sulit dan lambat untuk dibawa kepada kemajuan.

\section{Konsep Lesson Study}

\section{Pengertian Lesson Study}

Lesson Study yaitu suatu model pembinaan profesi pendidikan melalui pengkajian pembelajaran secara kolaboratif dan berkelanjutan berlandaskan prinsip-prinsipkolegalitasdanmutuallearninguntukmembangunkomunitas belajar. ${ }^{3}$ Sementara itu, menurut Hix ${ }^{4}$ menyebutkan bahwa "Lesson Study is a professional learning experience that allows teachers to collaboratively examine their own practice". Sedangkan di Jepang, Lesson Study is a process developed in Japan, in which a group of a teachers jointly design, teach, observe, analyze and revise a single class lesson, called Research Lesson.

Dengan demikian Lesson Study merupakan suatu model pembinaan profesi pendidik melalui pengkajian pembelajaran secara kolaboratif dan berkelanjutan berlandaskan prinsip-prinsip kolegalitas dan mutual learning untuk membangun learning community.

\section{Pelaksanaan Lesson Study}

Lesson Study sebagai kegiatan kolaboratif seharusnya dimulai dari kepala sekolah bersama guru sebagai inisiator. Pelaksana Lesson Study bergantung kepada model Lesson Study.

Model pertama adalah Lesson Study Berbasis Sekolah yang dilakukan dengan melibatkan semua guru dari berbagai bidang studi serta kepala

3 Hendaryana, S, dkk. Lesson Study: suatu Strategi untuk Meningkatkan Keprofesionalan Pendidikan (Pengalaman IMSTEP-JICA). (Bandung: UPI Press, 2006), hal. 10.

4 Hix, Sherry Love, Lesson Study.phd.pdf. Adobe Reader. Data Modified 11/5/2014, 12:18 PM. 2008, P. 36. 
sekolah. Berarti, Lesson Study berbasis sekolah dilaksanakan untuk meningkatkan kualitas pembelajaran setiap bidang studi. Di sekolah dasar, yang menggunakan sistem guru kelas, Lesson Study dilaksanakan untuk meningkatkan kulitas guru SD sebagai guru kelas serta untuk berbagi pengalaman mengajar di setiap kelas. Seluruh guru harus terlibat langsung dalam setiap tahapan Lesson Study, yaitu merencanakan, melaksanakan, dan merefleksi. Dalam Hendayana dkk. ${ }^{5}$ ditegaskan bahwa setiap guru berkesempatan untuk melakukan hal-hal berikut ini.
a. Identifiaksi masalah pembelajaran.
b. Mengkaji pengalaman pembelajaran yang biasa dilakukan.
c. Memilih alternatif model pembelajaran yang digunakan.
d. Merancang rencana pembelajaran.
e. Mengkaji kelebihan dan kekurangan alternatif model pembelajaran yang dipilih.

f. Melaksanakan pembelajaran.

g. Mengobservasi proses pembelajaran.

h. Mengidentifikasi hal-hal penting yang terjadi dalam aktivitas belajar siswa di kelas.

i. Melakukan refleksi secara bersama-sama atas hasil observasi kelas.

j. Mengambil pelajaran berharga dari setiap proses yang dilakukan untuk kepentingan peningkatan kualitas proses dan hasil pembelajaran lainnya.

Pada pelaksanaannya, sekolah mungkin saja melibatkan pihak luar sebagai tenaga ahli seperti dosen dari perguruan tinggi atau undangan lain yang dirasakan perlu dan berkepentingan.

Model kedua dari Lesson Study adalah Lesson Study Berbasis Kelompok Guru. Kelompok guru biasanya berdasarkan bidang studi pada wilayah kerja tertentu, misalnya MGMP atau KKG. Kegiatan Lesson Study biasanya dikoordinir oleh kelompok guru tersebut dan dibina oleh dinas pendidikan yang terkait. Beberapa tim ahli dari dosen juga dilibatkan beserta para mahasiswa dengan bidang yang sama. Hal ini bertujuan agar terjadi kerjasama ilmiah di antara praktisi pendidikan.

5 Hendaryana, S, dkk, Lesson Study: suatu Strategi untuk Meningkatkan Keprofesionalan Pendidikan (Pengalaman IMSTEP-JICA). (Bandung: UPI Press, 2006), hal. 10. 


\section{Kelebihan Lesson Study sebagi Suatu Bentuk Peningkatan Kualitas Pem- belajaran}

Saat ini, Lesson Study sudah menjadi salah satu model pembinaan guru di Jepang dan berdampak positif terhadap peningkatan kualitas proses dan hasil pembelajaran. Karena itulah, beberapa negara maju seperti Amerika dan beberapa negara eropa mengadopsi model pembinaan seperti ini. Mulai tahun 1998, Indonesian Mathematics and Science Teacher Education Project (IMSTEP) bekerjasama dengan IKIP Bandung (UPI), IKIP Yogyakarta (UNY), dan IKIP Malang (UNM) melaksanakan Lesson Study di beberapa wilayah di Indonesia.

Meskipun pada awalnya pilot project ini lebih ditekankan pada mata pelajaran yang eksakta (matematika dan sains) bukan berarti bahwa model ini tidak dapat diterapkan dalam ilmu social dan keagamaan. Hanya saja awal munculnya program ini, baik di Negara asalnya Jepang maupun Negara lain yang mengikuti model ini difokuskan pada mata pelajaran matematika dan sains. Untuk itu, elaborasi model ini dalam ilmu social atau keagamaan bukan berarti "haram" ataupun "makruh". Sebagai suatu model strategi pembinaan guru maka Lesson Study layak digunakan pada beberapa disiplin, karena di dalamnya memiliki keunggulan dan kelebihan. Sebagai model pembinaan guru, Lewis, Perry, dan Hurd (2003, Hendayana, dkk., 2006:38) mengemukakan keunggulan atau kelebihan Lesson Study seperti dalam gambar diagram 2.1 berikut: 
Gambar diagram 2

Keunggulan dan kelebihan Lesson Study

\begin{tabular}{|l|}
\hline Gambaran Umum Lesson \\
Study \\
kompetensi yang perlu dimiliki \\
siswa dan perkembangan siswa, \\
dan merencanakan lesson study \\
berdasarkan kompetensi \\
tersebut \\
> Observasi lesson study yang \\
berfokus pada pengumpulan \\
data tentang aktivitas belajar \\
siswa dan perkembangan \\
belajarnya \\
> Menggunakan data hasil \\
observasi untuk melakukan \\
refleksitentang pembelajar an \\
secara mendalam dan lebih luas \\
> Jika diperlukan, melaku kan \\
perencanaan ulang dengan \\
topik yang sama untuk \\
melakukan lesson study pada \\
kelas berbeda
\end{tabular}

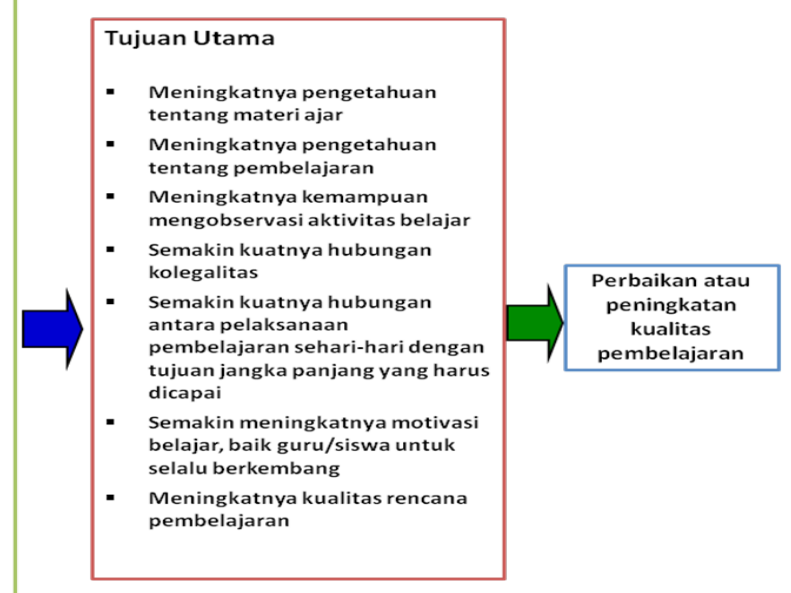

Sumber: diadaptasi dari Hendayana, dkk (2006:39)

Dengan demikian jelaslah bahwa beberapa kelebihan Lesson Study yang mulai diterapkan pada tahun 2004 hasilnya adalah sebagai berikut:

a. menunjukkan terjadinya peningkatan profesionalisme guru dalam melakukan pembelajaran di sekolah,

b. meningkatkan kolaborasi akademik dan dapat dilakukan secara berkelanjutan.

Keberhasilan ini tidak terlepas dari efektifitas dan efisiensi program Lesson Study yang ditunjang oleh kegiatan monitoring dan evaluasi (MONEV) dengan menggunakan rekaman audiovisual, menjadikan para guru dapat mengkaji mutu pembelajaran berdasarkan data dan fakta yang sesungguhnya.

\section{Pentahapan Lesson Study}

Lesson Study sebagai bentuk pembinaan guru memiliki 3 (tiga) tahapan yaitu merencanakan (plan), melaksanakan (do), dan merefleksi (see) yang berupa kegiatan yang berkelanjutan. Siklus pentahaan lesson studi dapat diamati pada gambar 2.2 di bawah ini: 
Gambar 3

Pentahapan Lesson Study

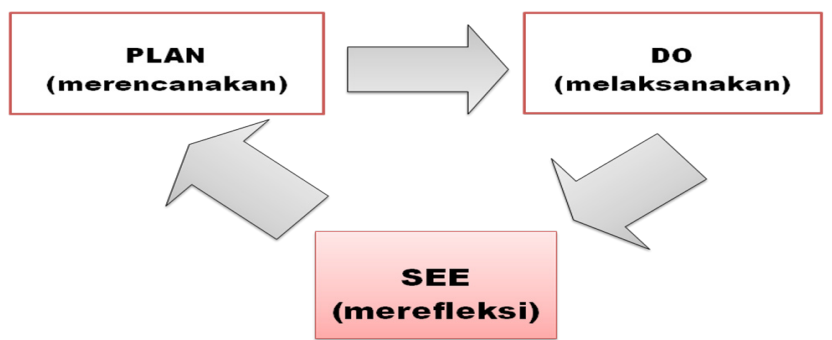

Sumber: Diadaptasi dari Lesson Study Tuwuh, ppt, 2014

Sementara itu,berdasarkan proyek Lesson Study di Jepang dapat digambarkan sebagai berikut:

Gambar 4

Lesson Study Project Cycles

Re-teach, Study \&

Document Lesson

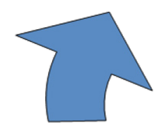

Analyze Evidence \&

Revise Lesson
Develop Student

Learning Goals

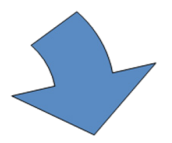

Design \& Plan the Lesson

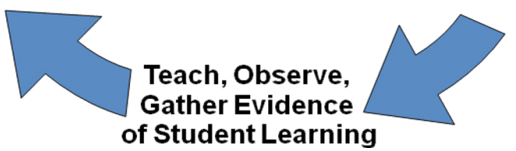

Sumber: Diadaptasi dari Lesson Study Tuwuh, ppt, 2014

Dari kedua model tersebut, sebenarnya intinya sama.

Model gambar 2.2 adalah model pentahapan yang sudah disederhanakan dan disesuaikan dengan kondisi di Indonesia. 


\section{Gambar 5 \\ Model Lesson Study Dalam Bentuk Hirarki.}

- a small group of teachers collaboratively ...

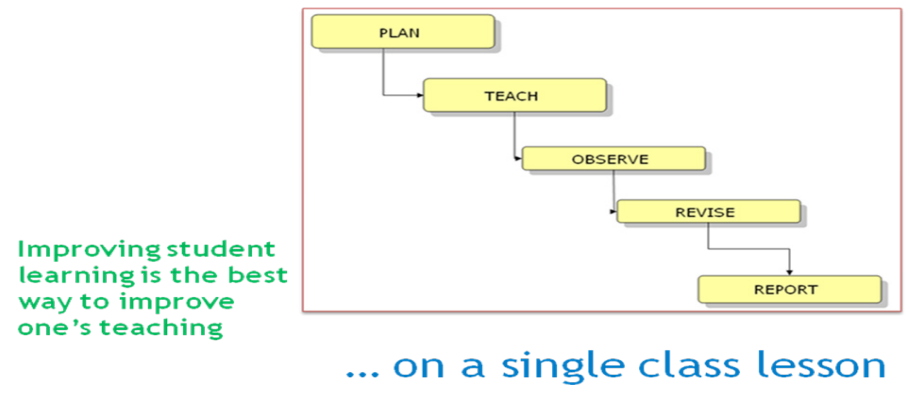

Sumber: Diadaptasi dari Lesson Study Tuwuh, ppt, 2014

Pentahapan selengkapnya diuraikan pada paparan berikut:

\section{a. Merencanakan (Plan)}

Dalam tahap ini seorang guru bersama koleganya melakukan serangkaian kegiatan sebagai berikut:

1) Identifikasi Masalah

2) Didiskusikan dalam Community Learning

3) Sumbangan pemikiran terhadap masalah

4) Penyusunan lembar observasi

5) Penyusunan perangkat pembelajaran :

a) RPP

b) LKS

c) Media / alat peraga pembelajaran

d) Instrumen penilaian proses dan hasil belajar

e) Lembar Observasi Pembelajaran

\section{b. Melaksanakan (Do)}

Pada tahap pelaksanaan, kegiatan yang dilakukan di dalamnya adalah:

1) Guru mengimplementasikan perencanaan

2) Guru yang lain mengamati/observasi praktik pembelajaran

3) Dosen (ahli)/kepala sekolah juga sebagai pengamat.

Ahli yang dimaksud di dalam tahapan ini sesungguhnya lebih 
ditekankan pada guru atau pendidik yang lebih senior atau advanced yang memiliki pengalaman pembelajaran lebih dan expertise dalam menyelesaikan berbagai permasalahan dalam sebuah proses pembelajaran.

\section{c. Merefleksi (See)}

Pada tahap ini guru praktikan akan memperoleh feed back dari rekanrekannya yang lain untuk merefleksikan apa yang telah dilakukannya, apakah sudah sesuai dengan rencana ataukah belum sesuai. Refleksi ini meliputi:

1) Diskusi guru, pengamat (observer) dipimipin oleh kepala sekolah atau guru senior.

2) Komentar-komentar dari pengamat

3) Masukan dari pengamat dijadikan sebagai perbaikan pembelajaran berikutnya

Demikianlah 3 (tiga) tahapan dalam Lesson Study yang mesti harus dilalui oleh seorang guru ketika yang bersangkutan sebagai model dalam proses Lesson Study. Intinya seorang guru model harus siap mendapatkan masukan ataupun kritik dari teman komunitasnya atau bahkan dari para peserta didik tentang pembelajaran yang dilakukannya. Pada kegiatan Lesson Study seorang observer atau pengamat tidak boleh menegur langsung apabila guru model mengalami kekeliruan atau pun melakukan sesuatu yang seharusnya dilakukan, karena dalam Lesson Study observer mempunyai waktu khusus untuk mengevaluasi yaitu pada saat refleksi. Hal yang lebih menarik dalam Lesson Study kekurangan yang ditemukan dalam pembelajaran dapat diperbaiki langsung perencanaannya dan kemudian dipraktikan lagi, demikian seterusnya sehingga akan tercapai komunikasi, sikap dan perilaku yang terbaik dalam pembelajaran. Sisi lain yang juga menarik dalam Lesson Study adalah mobilitas pertukaran peran antara guru model, observer sehingga saling mengevaluasi dan memacu untuk berbuat yang terbaik. 


\section{Lesson Study sebagai sarana meningkatkan kualitas dan profesio- nalitas pembelajaran.}

Telah dikemukakan pada paparan sebelumnya bahwa Lesson Study merupakan wahana yang sangat baik untuk memperbaiki kualitas guru dalam pembelajaran. Alasan ini didasarkan pada kenyataan bahwa kualitas pembelajaran sangat ditentukan oleh profesionalitas guru dalam pembelajaran. Intensitas perbaikan yang terdapat dalam proses Lesson Study mendorong guru berbuat secara optimal yang pada gilirannya akan membuat habit yang baik dan akhirnya mampu membangun academic culture dalam pembelajaran di kelas maupun di luar kelas. Inilah salah satu alasan kenapa lesson Study itu penting bagi guru dan menjadi alasan mengapa Lesson Study perlu diimplementasikana adalah sebagai berikut:

1. pengembangan Lesson Study dilakukan dan didasarkan pada hasil "sharing" pengetahuan profesional yang mempertimbangkan pada praktek dan hasil pembelajaran yang dilaksanakan para guru,

2. penekanan dari Lesson Study adalah para siswa agar memiliki kualitas belajar,

3. Pengembangan kompetensi siswa dijadikan fokus dan titik perhatian utama dalam pembelajaran di kelas,

4. berdasarkan pengalaman real di kelas, Lesson Study mampu menjadi landasan bagi pengembangan pembelajaran, dan

5. Lesson Study akan menempatkan peran para guru sebagai peneliti pembelajaran.

Dengan melaksanakan Lesson Study para guru secara kolaboratif akan dapat:

1. menentukan kompetensi yang perlu dimiliki siswa, satuan (unit) pelajaran dan materi pelajaran yang efektif;

2. mengkaji dan meningkatkan pembelajaran yang bermanfaat bagi siswa;

3. memperdalam pengetahuan tentang materi pelajaran yang disajikan para guru;

4. menentukan tujuan jangka panjang yang akan dicapai para siswa;

5. merencanakan pelajaran secara kolaboratif;

6. mengkaji secara teliti proses pembelajaran dan perilaku siswa; 
7. mengembangkan pengetahuan pembelajaran yang andal; dan

8. melakukan refleksi terhadap pembelajaran yang dilaksanakannya berdasarkan pandangan siswa dan kolega guru.

Selain beberapa alasan tersebut ada alasan lain yang memperkuat mengapa Lesson Study menjadi alternative dalam rangka memperbaiki kualitas dan profesionalitas guru dalam pembelajaran, yaitu pengalaman dari Negara Hong Kong yang sekarang masuk ke dalam "one of State of Tiger East Asia" dan masuk dalam jajaran Negara maju. Berdasarkan pada laporan yang dibuat oleh LOMun Ling (2003) ketua Centre for the Development of School Partnership and Field Experience Hong Kong yang berjudul "Lesson Study and its Impact on Teacher Development".

Banyak perubahan dalam bidang pendidikan di Hong Kong yang berkaitan dengan kualitas proses pembelajaran. Bagaimanapun, para guru sering mengeluh bahwa perubahan yang retorik adalah samar-samar dan sukar untuk yang diterapkan kelas. Dr. LO Mun Ling terinspirasi ketika membaca tentang Lesson Study di Jepang dari buku Teaching Gap" karya Stigler dan Hiebert (1999) dalam Lidinillah (2014:6-7). Ia kemudian melihat peluang bahwa dengan Lesson Study dapat menghilangkan kesenjangan antara perubahan retorik dan praktek di kelas.

Bersama-sama dengan suatu tim peneliti dari Universitas Hong Kong, ia pertama mencoba untuk mengadopsi Lesson Study dalam konteks Hong Kong pada tahun 1999, dengan waktu penelitian dalam tiga tahun. Lesson Study untuk pengembangan profesional dengan cepat dikenali, dan telah dimodifikasi untuk dikembangan suatu Lesson Study versi Hong Kong. Di Amerika dan banyak negara-negara Eropa, Lesson Study telah menjadi suatu wilayah penelitian yang sangat penting. Itu diantisipasi bahwa Lesson Study akan mendukung semua aspek pendidikan: pre-service, pengembangan guru berkelanjutan, penelitian dan pengembangan dalam pendidikan, dan juga untuk meningkatkan status profesi secara keseluruhan.

Suatu Lesson Study yang baik menunjukkan berbagai kemungkinan untuk mengaplikasikan teori bidang pendidikan ke dalam konteks para guru di kelas. Itu dapat juga membantu para guru untuk mengubah bentuk perubahan yang retorik ke dalam praktek. Dari hasil wawancara terhadap guru berkenaan dengan kegiatan Lesson Study di Hongkong tahun 
2001-2002, para guru ini melaporkan bahwa mereka sudah memperoleh pengertian yang mendalam tentang berbagai hal berikut.

1. Pandangan guru terhadap para siswa mengalami perubahan, yaitu terjadi pergeseran tentang cara memahami perbedaan individu serta guru menemukan kenyataan bahwa murid yang sebelumnya dianggap memiliki kemampuan rendah ternyata dapat menunjukkan kelebihannya.

2. Para guru memiliki pandangan baru tentang bagaimana memotivasi siswa dalam pembelajaran. Pemahaman yang baik tentang siswa dapat dijadikan dasar untuk merencanakan pembelajaran. Guru mengakui bahwa selama ini kurang memahami siswa dengan baik termasuk ketika menghadapi permasalahan.

3. Para guru memperoleh pemahaman yang lebih baik tentang fungsi penilaian dalam pembelajaran. Jika pembelajaran direncanakan menurut hasil pre-test, maka hasil post-test adalah sangat penting untuk menunjukkan bagaimana para siswa dapat belajar atau apakah mereka masih mempunyai berbagai kesulitan. Dengan pre-test dan post-tes yang baik dapat mengatasi masalah siswa dalam pembelajaran.

4. Para guru memiliki pandangan yang berbeda tentang apa yang akan diajarkan (subject matter), apa yang mendasari kurikulum, serta peran mereka sendiri sebagai guru. Guru mendapatkan cara baru dalam teknik-teknik pembelajaran, kaitannya dengan kurikulum dan apa yang harus mereka lakukan.

\section{E. Cara Mengatasi agar Lesson Study Secara Konsisten Digunakan dalam Meningkatkan Kualitas dan Profesionalitas Pembelajaran Guru.}

Suatu euphoria yang lazim kita lihat pada perwajahan pendidikan Indonesia adalah marak dan gairah yang tinggi untuk mengimplementasikan sebuah program baru. Demikian halnya dengan Lesson Study, program ini sempat marak dan menjadi "booming" pada tahun 2009/2010 di Yogyakarta. Bahkan beberapa sekolah piloting "laris manis" diundang ke sekolah di sekitarnya untuk mensosialisasikan program Lesson Study. Sekolah negeri maupun swas- 
ta, baik yang ada di bawah naungan Kemendiknas maupun Kemenag berbondong-bondong mengadopsi model ini untuk memperbaiki proses dan kualitas pembelajarannya yang memang terbukti secara efektif dan inovatif dalam memperbaiki kinerja guru.

Namun ironinya, sekarang model Lesson Study yang menjadi program dan strategi efektif dalam membangun kualitas dan profesionalitas pembelajaran guru sudah mulai berkurang dalam implementasinya pada proses pembelajaran di beberapa sekolah. Situasi ini memunculkan sebuah pertanyaan: Ada apa dengan Lesson Study? Mengapa sekarang kurang "greget" dalam implemntasi di sekolah-sekolah? Di mana letak kesalahannya?

Untuk menjawab beberapa pertanyaan tersebut, maka kita harus melihat secara arif kenapa sebuah program peningkatan profesionalisme guru yang baik hanya ditinggalkan begitu saja. Sebenarnya tidak ada yang salah dengan Lesson Study, karena secara teoritik maupun praksis model pembinaan ini termasuk kategori "ideal", meskipun kita dapat memungkiri bahwa "tidak ada satupun model yang paling baik dalam segala situasi". Kekurangkonsistenan dalam mengimplementasikan Lesson Study mungkin lebih disebabkan karena minimnya waktu luang guru untuk mengaplikasikan program ini. Sejak adanya pergantian kurikulum, baik KTSP maupun Kurikulum 2013, guru banyak disibukkan dengan berbagai kegiatan administrasi akademik yang menyita waktu untuk secara bersama-sama berkolaborasi mengembangkan "sharing" pembelajaran dalam komunitas kolegial.

Selain karena faktor guru, factor lainnya yang nampaknya menjadi penyebab turunnya "ghirah" terhadap aplikasi Lesson Study adalah komitmen dari kepala sekolah dan pihak berwenang terkait juga kurang intens, termasuk keterlibatan pihak perguruan tinggi dan masalah ketersediaan sarana dan prasarana. Lidinillah (2014:7-9) memaparkan pendapat Hendaryana, dkk. (2006) yang mencoba mengaitkan Lesson Study sebagai bentuk inovasi pembelajaran mengidentifikasi beberapa masalah yang menjadi penyebab kurangnya implementasi Lesson Study di sekolah, yaitu: faktor sumber daya manusia, sarana prasarana dan kebijakan teknis.

Pada faktor sumber daya manusia, idealnya Lesson Study muncul dari inisiatif Kepala Sekolah bersama guru. Siapa yang terlibat dalam Lesson Study tergantung model Lesson Study yang digunakan. Jika yang digunakan adalah 
Lesson Study berbasis sekolah maka yang terlibat adalah guru-guru dan kepala sekolah pada suatu sekolah. Sedangkan jika Lesson Study berbasis KKG atau MGMP, maka yang dilibatkan guru-guru dalam suatu gugus kerja, misalnya untuk guru sekolah dasar dalam suatu Unit Pelaksana Teknis Dinas (UPTD) Pendidikan. Dalam pelaksanaannya, berbagai pihak dari dinas terkait, termasuk pengawas juga dapat dilibatkan. Sementara untuk pertimbangan ahli dapat melibatkan dosen dan mahasiswanya sebagai sarana pembelajaran dan latihan di lapangan. Identifikasi dari sektor SDM muncul karena: belum seragamnya pemahaman tentang Lesson Study, kesiapan kerja tim, dan koordinasi yang harus melibatkan banyak unsur karena kegiatan ini bersifat kolaboratif.

Dari sisi sarana prasarana, pelaksanaan Lesson Study sebenarnya cukup mudah karena di lakukan di sekolah dengan seizin dari pihak sekolah. Adapun yang sering menjadi kendala adalah justru biaya operasional pelaksanaan Lesson Study, meliputi transport yang harus memperimbangkan jauh dekatnya rayon sekolah yang ada, alat-alat pembelajaran, dan konsumsi pelaksanaan. Selain itu ruang kelas sering tidak memadai untuk dimasuki para observer dengan jumlah yang sedikit banyak. Alat-alat pembelajaran yang bervariasi harganya tentunya membutuhkan alokasi dana khusus dan memerlukan masuk dalam anggaran.

Sedangkan dari sisi kebijakan teknis, dari beberapa pengalaman pelaksanaan Lesson Study di Indonesia masih tergantung dari proyek IMSTEP yang melibatkan Perguruan tinggi, yaitu UPI Bandung, UNY Yogyakarta dan UM Malang. Hal ini menjadi kurang efektif, karena seharusnya pihak sekolah dan Dinas Pendidikan di Daerahlah yang mestinya proaktif untuk mensosialisasikan program ini.

Untuk mengatasi beberapa problem di atas, maka beberapa langkah yang harus ditempuh mengingat pentingnya Lesson Study sebagai bentuk meningkatkan kualitas dan provesionalitas sekaligus sebagai inovasi Pendidikan. Menurut Roger (1993), suatu inovasi akan diterima dengan cepat atau tidaknya bergantung kepada hal-hal berikut, yaitu :

1. Keuntungan relatif, yaitu sejauhmana inovasi dianggap menguntungkan bagi penerimanya, dari segi-segi: ekonomi, faktor status sosial, kesenangan atau kepuasan.

2. Kompatibel, yaitu tingkat kesessuian inovasi dengan nilai, pengalaman, dan kebutuhan penerima. 
3. Kompleksitas, yaitu tingkat kesukaran utuk memahami dan menggunakan inovasi bagi peneriman.

4. Triabilitas, ialah dapat dicoba atau tidaknya suatu inovasi oleh penerima.

5. Dapat diamati, ialah mudah tidaknya suatu hasil inovasi.

Sementara keputusan suatu inovasi itu akan diadaptasi atau tidaknya mengikuti 5 langkah, yaitu: (a) pengetahuan tentang inovasi, (b) bujukan dan imbauan, (c) penetapan atau keputusan, (d) penerapan, dan (e) konfirmasi.

Berdasarkan asumsi teori tersebut, maka untuk mengatasi masalahmasalah yang terjadi dalam pelaksanaan Lesson Study agar implementasinya dapat dilaksanakan secara konsisten dengan melibatkan berbagai pihak yang peduli dan concern pada pendidikan langkah yang ditempuh adalah sebagai berikut:

\section{Solusi terhadap Masalah Sumber Daya Manusia.}

Masalah sumberdaya manusia selalu menjadi hambatan dalam setiap usaha inovasi, baik cara pandang, prilaku, kebiasaan atau persepsi tentang suatu inovasi dan perbaikan kualitas dan profesionalitas. Oleh karena itu, dalam kasus pelaksanaan Lesson Study di Indonesia faktor inisiatif dari guru dan sekolah manapun dinas terkait masih kurang. Beberapa hal yang dapat dilakukan adalah:

a. Mengintensifkan kegiatan-kegiatan ilmiah untuk menyebarkan pengetahuan dan pengalaman pelaksanaan Lesson Study.

b. Melibatkan guru-guru dalam kegiatan ilmiah tersebut.

c. Mengembangkan model-model percontohan kegiatan Lesson Study.

d. Meningkatkan partisipasi KKG dan MGMP dalam kegiatan Lesson Study bahkan dapat dijadikan sebagai pelaksana di lapangan.

e. Memahamkan kepada guru bahwa Lesson Study dapat digunakan sebagai bagian penelitian tindakan kelas (PTK).

\section{Solusi terhadap Masalah Sarana Prasarana}

Sarana yang digunakan dalam kegiatan Lesson Study tidak lah sulit untuk dicari. Hanya saja sulitnya mencari sekolah yang memiliki kelengkapan fasilitas yang dibutuhkan terutama di daerah. Biaya yang 
tidak kalah pentingnya adalah biaya operasional kegiatan yang sering menjadi kendala terutama jika kegiatan Lesson Study tidak berbasis proyek. Beberapa hal yang dapat dialakukan untuk memecahkannya adalah :

a. Mengembangkan komitmen dinas pendidikan untuk mengalokasikan kegiatan Lesson Study

b. Mengembangkan komitmen sekolah dalam mengalokasikan biaya operasinal bagi guru yang terlibat dalam Lesson Study

c. Pihak perguruan tinggi mengembangkan proyek-proyek Lesson Study untuk diajukan pada lembaga-lembaga pemerintah atau internasional.

\section{Solusi untuk Masalah Kebijakan Teknis}

Kebijakan pelaksanaan Lesson Study sudah direspon dengan baik oleh pemerintah pusat. Hanya saja, pelaksana program pendidikan tingkat daerah belum semuanya mengadaptasi Lesson Study sebagai sebuah inovasi. Padahal kebijakan teknis tingkat daerah sangat dibutuhkan untuk mendorong sekolah-sekolah. Oleh karena itu, perlu usaha sosialisasi dan persuasi yang lebih intensif dengan pemerintah daerah.

Oleh karena Lesson Study secara teoritik maupun praktik sebenarnya tidak sulit untuk dipraktekkan, maka tinggal komitmen dari semua pihak sajalah yang akan mampu mengangkat program ini sebagai model dalam memperbaiki kinerja guru dalam pembelajaran.

\section{F. Manfaat Lesson Study}

Lesson Study sebagai bentuk inovasi pendidikan dan menjadi sarana yang efektif bagi peningkatan mutu dan profesionalisme guru memiliki beberapa manfaat penting sebagaimana dikemukakan oleh Tim Lesson Study (2007:8), yaitu:

1. Mengurangi keterasingan guru (dari komunitasnya) dalam perencanaan, pelaksanaan pembelajaran dan perbaikannya.

2. Membantu guru untuk mengobservasi dan mengkritisi pembelajarannya. 
3. Memperdalam pemahaman guru tentang materi pembelajaran, cakupan dan urutannya.

4. Membantu guru dalam peningkatan yang memfokuskan pada seluruh aktifitas belajar peserta didik.

5. Meningkatkan kolaborasi antar sesama guru dalam pembelajaran.

6. Meningkatkan mutu guru dan mutu pembelajaran yang pada gilirannya berakibat pada peningkatan mutu lulusan (peserta didik).

7. Member kesempatan kepada guru untuk membuat menjadi bermakna, ide-ide pendidikan dalam praktek pembelajarannya bermakna sehingga dapat mengubah perspektif tentang pembelajaran, dan belajar praktek pembelajaran dari perspektif peserta didik.

8. Mempermudah guru berkonsultasi kepada pakar dalam hal pembelajaran atau kesulitan materi pembelajaran.

Demikian beberapa aspek tentang Lesson Study, baik dari sisi konsep, langkah dan manfaat yang dihasilkannya sehingga mampu menjadi sarana untuk meningkatkan inovasi, mutu dan profesionalitas guru. Namun demikian hal yang tidak kalah penting untuk dipahami oleh para pendidik, khususnya pengelola pendidikan adalah pemahaman tentang Lesson Study sebagai bagian dari supervisi pendidikan. Lesson Study harus dipahami secara integrative dan komprehensif sebagai bagian dari upaya membentuk quality culture pada suatu institusi pendidikan yang menyediakan pelayan (service provider) bagi stakeholders. Oleh karena itu, Menurut Satori (2014) dalam sesi perkuliahan Teori dan Praktik Supervisi menjelaskan bahwa untuk menumbuhkan awwareness of quality culture pada institusi pendidikan maka perlu dibangun suatu system yang komprehensif mulai dari quality control (QC), quality assurance (QA), total quality management (TQM) dan continuous quality improvement (CQI) sampai terbentuknya quality culture (QC) (Kamis, 25 September 2014).

Untuk itu, satu mekanisme yang nampaknya "wajib dibuat" dan "tidak boleh ditunda lagi" adalah membuat suatu regulasi tentang mekanisme reward terhadap kinerja guru berbasis pengembangan profesionalitas. Pemberian reward terhadap guru diberikan ketika guru mampu memberikan prestasi dan komitmen terhadap profesinya sehingga tercapai asas keadilan. Adapun konsekuensinya guru yang tidak mau berkembang harus diberi warning dengan tindakan tegas berupa pemberian sanksi pemberhentian sebagai tenaga 
professional akademik atau alih ke tugas yang bersifat administrative. Pemikiran ini harus ditanamkan kepada setiap guru karena peran supervisi adalah mengembalikan kedudukan, fungsi dan tugas guru pada kepatuhan akademik melalui peningkatan kualitas dan profesionalitas dalam pembelajaran.

\section{G. Penutup}

Setelah membahas Lesson Study, maka penulis berkesimpulan bahwa Lesson Study merupakan bagian dari supervisi pendidikan yang bertujuan untuk membina dan meningkatkan profesionalitas guru melalui model pembinaan profesi pendidik melalui pengkajian pembelajaran secara kolaboratif dan berkelanjutan berlandaskan prinsip-prinsip kolegalitas dan mutual learning untuk membangun learning community.

Lesson Study sebagai satu model pembinaan guru akan dapat diimplementasikan secara efektif di lembaga pendidikan dengan syarat terdapat komitmen bersama yang kuat dari para guru sendiri, kepala sekolah dan pihak Dinas Pendidikan setempat didukung oleh keterlibatan para pakar pendidikan.

Lesson Study bukan satu-satu model pembinaan profesi guru, oleh karenanya perlu dikombinasikan dengan model lainnya, seperti pengembangan keprofesian berkelanjutan (PKB), kerja kelompok guru (KKG), musyawarah guru mata pelajaran (MGMP), penataran guru, in-house training, penilaian kinerja guru (PKG) dan penelitian tindakan kelas (PTK).

\section{DAFTAR PUSTAKA}

Digital Qur'an Ver 3.2. Data Created: 3/22/2012 2:20 PM Size 2.75MB Hendaryana, S, dkk. 2006. Lesson Study: suatu Strategi untuk Meningkatkan Keprofesionalan Pendidikan (Pengalaman IMSTEP-JICA). Bandung UPI Press

Hendaryana, Sumar, dkk. 2007 Lesson Study Suatu Strategi Untuk Meningkatkan Keprofesionalan Pendidik. Bandung: FMIPA UPI dan JICA

Hix, Sherry Love. 2008. Lesson Study.phd.pdf. Adobe Reader. Data Modified 11/5/2014, 12:18 PM.

Lidinillah, Dindin, Abul Muiz. 2014. Lesson Study Sebagai Inovasi Untuk Peningkatan Mutu Guru. Lesson Study.pdf. Akses 11/5/2014: 12:24 PM 
Nuryanta, Nanang. 2014. Reorientasi Pendidikan Nasional Dalam Menyiapkan Daya Saing Bangsa. Makalah. Bandung: SPS UPI.

Ornstein, Allan C, Levine, U Daniel, Gutek, Gerald L, and Vocke, David E. 2011. Foundations of Education. Eleventh Edition. USA: Wardworth Engage Learning

Roger, M. (1983). Diffusion of Inovation. New York: The Free Press A Division of Macmillan Publishing, co. Inc.

Sanjaya, Wina. 2008. Strategi Pembelajaran Berorientasi Standar Proses Pendidikan. Jakarta: Kencana Prenada Media Group.

Santosa, Adam. 2014. Pengaruh Pembelajaran Dengan Lesson Study Terhadap Hasil Belajar Pendidikan Agama Islam (PAI) Di SMP Negeri 1 Srandakan Bantul Yogyakarta Tahun Pelajaran 2013/2014. Proposal Tesis. Yogyakarta: PPS MSI UII

Satori, Djam'an. 2014. Sesi Perkuliahan Teori dan Praktik Supervisi Pendidikan. Bandung: SPS UPI pada Kamis, 25 September 2014 dan 13 November 2014.

Tim Lesson Study. 2007. Rambu-Rambu Pelaksanaan Lesson Study. Yogyakata: FMIPA UNY. 
318 Millah Vol. XIV, No. 2, Februari 2015 